\title{
Diversity of ancient woody species in urban forests
}

\author{
Beata Fornal-Pieniak ${ }^{1} \bowtie$, Marcin Ollik$^{2}$, Ewa Zaraś-Januszkiewicz ${ }^{1}$, Barbara Żarska \\ ${ }^{1}$ Warsaw University of Life Sciences - SGGW, Faculty of Horticulture, Biotechnology and Landscape Architecture, \\ Department of Environment Protection, Nowoursynowska 159, 02-787 Warsaw, Poland, \\ e-mail: beata_fornal_pieniak@sggw.pl \\ ${ }^{2}$ Warsaw University of Life Sciences - SGGW, Faculty of Agriculture and Biology, Department of Experimental Design \\ and Bioinformatics, Nowoursynowska 159, 02-787 Warsaw, Poland
}

\section{Abstract}

Mostly parks and forest are the most important 'green islands' in urban ecological network. Urban forests are belong to green areas and collected many plant species. The main aim of the article was characteristic of ancient plant species in urban forests in Tarnów. The field studies were carried out in years 2011-2012. It covered 80 phytosociological records on the area $500 \mathrm{~m} 2$ in herb layer of urban forests and in forest nature on oak-hornbeam. The results showed that many ancient plant species were growing in urban forest but less than in nature reserves.

\section{KEY WORDS}

ancient woody species, urban forest

\section{INTRODUCTION}

Urban areas are highly modified and complex landscapes, within which green or open areas are seen as valuable for human well-being as well as wildlife (Pickett et al. 2001, 2004). Many cities have a network of habitat fragments or 'urban greenways' comprising areas of semi-natural habitats, secondary succession, ruderal and pioneer environments and open areas. These habitats may be important features for biodiversity both as stable and as transient habitats (McIntyre 2000; McIntyre et al. 2001) and may also be valuable for their possible function as "corridors" and "stepping stones' to facilitate species dispersal Kirby (1995). Parks and urban forest are the most important elements in urban ecological network. Ancient forest plant species - plant species which are characteristic for ancient woodland (above 200 year old) and old woodlands (200-100 years old) according to Wulf (2003). The main aim of the article was characteristic of ancient woody plant species in urban forest in Tarnów.

\section{Material AND MEthods}

Tarnow is a city in southeastern Poland $\left(50^{\circ} 00^{\prime} 45^{\prime \prime} \mathrm{N}\right.$ $\left.20^{\circ} 59^{\prime} 18^{\prime \prime} \mathrm{E}\right)$. The city has been situated in the Lesser Poland Voivodeship.

It covered 80 phytosociological records on the area $500 \mathrm{~m}^{2}$ in herb layer of urban forests and in forest nature on oak-hornbeam habitat (4 objects), reserves (4 objects, located out of the city); 160 - total numbers of records. 
Flora analysis included number of "ancient plants" on study areas.

\section{Results}

The occurring plant species were represented by forest plants (Tilio-Carpinetum), grasses plants (Molinio-Arrhenatheretea), synantropical plants (Artemisietea vulgaris). It was observed higher frequently and diversity of plant species in nature reserve (29 species) than in the urban forests (23 species) (tab. 1). Native, ancient species for example Anemone nemerosa, Stellaria holostea, Corydalis cava, Anemone ranunculoides are strongly connected with natural habitats.

Table 1. List of ancient plant species in nature reserves and urban forests

\begin{tabular}{|l|l|}
\hline \multicolumn{1}{|c|}{ Nature reserves } & \multicolumn{1}{|c|}{ Urban forests } \\
\hline \multicolumn{1}{|c|}{ 2 } & \\
\hline Acer campestre & Acer campestre \\
\hline Anemone nemerosa & Anemone nemerosa \\
\hline Anemone ranunculoides & Anemone ranunculoides \\
\hline Asarum europaeum & Asarum europaeum \\
\hline Carex pilosa & Circaea lutetiana \\
\hline Circaea lutetiana & Convallaria majalis \\
\hline Convallaria majalis & Corydalis cava \\
\hline Corydalis cava & Corylus avellana \\
\hline Corylus avellana & Dactylis polygama \\
\hline Dactylis polygama & Gagea lutea \\
\hline Gagea lutea & Galeobdolon luteum \\
\hline Galeobdolon luteum & Luzula pilosa \\
\hline Lathyrus vernus & Maianthemum bifolium \\
\hline Luzula pilosa & Melampyrum nemorosum \\
\hline Maianthemum bifolium & Mercurialis perennis \\
\hline Melampyrum nemorosum & Oxalis acetosella \\
\hline Melica nutans & Poa nemoralis \\
\hline Mercurialis perennis & Polygonatum multiflorum \\
\hline Milium effusum & Pulmonaria officinalis \\
\hline Oxalis acetosella & Stachys sylvatica \\
\hline Paris quadrifolia & Stellaria holostea \\
\hline Phyteuma spicatum & Tilia cordata \\
\hline
\end{tabular}

\begin{tabular}{|l|l|}
\hline \multicolumn{1}{|c|}{1} & \multicolumn{1}{c|}{2} \\
\hline Poa nemoralis & Viola mirabilis \\
\hline Polygonatum multiflorum & \\
\hline Pulmonaria officinalis & \\
\hline Stachys sylvatica & \\
\hline Stellaria holostea & \\
\hline Tilia cordata & \\
\hline Viola mirabilis & \\
\hline
\end{tabular}

\section{Conclusions}

- Oak hornbeam sites in urban forests are not so disturbanced by anthropogenic pressure because ancient plants are still occurring there.

- More ancient plants were growing in nature reserves than urban forests.

\section{References}

Braun-Blanquet J. 1951. Pflanzensoziologie. Springer Verlang, Wien.

Matuszkiewicz J.M. 2001. Zespoły leśne Polski (Forest communities in Poland). PWN, Warsaw.

McIntyre N.E. 2000. Ecology of urban arthopools: a review and a call to action. Annals of the Entomological Society of America, 93, 825-835.

McIntyre N.E., Rango J., Fagan W.F., Faeth S.H. 2001. Ground arthopool community structure in a heterogeneous urban environment. Landscape and Urban Planning, 52, 257-274.

Pickett S.T.A., Candenasso M.L., Grove J.M. 2004. Resilient cities: meaning, models and metaphor for integraing the ecological socio-economic and planning realms. Landscape and Urban Planning, 69, 369-384.

Pickett S.T.A., Candenasso M.L., Grove J.M., Nilon C.H., Pouyat R.V., Zippere W.C. 2001. Urban ecological systems: linking terrestrial ecological, physical, and socioeconomic components of metropolitan areas. Annual Review of Ecology and Systematics, 32, 127-157.

Wulf M. 2003. Preference of plant species for woodlands with differing habitat continuities. Flora, 198, 444-460. 